\title{
A IRONIA DO NARRADOR E O DRAMA TRÁGICO DA HOSPITALIDADE CANIBAL EM DOGVILLE, DE LARS VON TRIER
}

\author{
Carlos Cézar Mascarenhas de Souza ${ }^{1}$
}

\begin{abstract}
Resumo: Este artigo tem por objetivo abordar, a partir da enunciação irônica que afeta a voz do narrador no filme Dogville, do cineasta Lars Von Trier, a imagem de um destino trágico em função do "Drama da hospitalidade canibal”, à luz da psicanálise freudo-lacaniana articulada às contribuições de Jacques Derrida e Emmanuel Lévinas.

Palavras-Chave: Hospitalidade; Drama; Ironia; Linguagem.

Resumen: El artículo tiene el objetivo de tratar, a partir de la enunciación irónica que afecta la voz del narrador de la película Dogville, del director Lars Von Trier, la imagen de un destino trágico por cuenta del "Drama de la hospitalidad caníbal", bajo la luz de la psicoanálisis freudiana y lacaniana, en articulación con las contribuciones de Jacques Derrida e Emmanuel Lévinas.

Palabras Clave: Hospitalidad; Drama; Ironía; Lenguaje.
\end{abstract}

\section{INTRODUÇÃO}

Dogville pode ficar longe de tudo, mas é muito hospitaleira, é claro (Comentário do narrador de Dogville; no capítulo IX - grifo meu).

Claro, o mundo da imagem existe, mas só nos interessa por sua utilização simbólica, na medida em que é tomado no universo do símbolo e ali cumpre uma função (Jacques Lacan, O mito individual do neurótico, ou, A poesia e verdade na neurose).

O presente artigo se propõe como uma ponte, pela qual se cruzem em diálogo os discursos estético-cinematográfico com o psicanalítico de matiz freudo-lacaniana, levando em conta as contribuições dos filósofos Jacques Derrida e Emmanuel Lévinas no que se refere à questão da hospitalidade, tendo ainda como suporte das nossas elaborações a representação fílmica em Dogville. A escolha deste filme tem por mérito nos oferecer a oportunidade de enfocar a imagem trágica no drama, quando este se envereda pela via do que aqui denomino por "drama trágico da hospitalidade canibal".

1 Doutor em Teoria Literária pela Universidade Federal de Pernambuco (UFPE); Psicanalista e Psicólogo Clínico. Endereço eletrônico: c.mascarenhas@bol.com.br. 
Desde logo, como já advertira Lévinas², vale salientar que a problemática da hospitalidade transborda a simples pretensão ao mero exercício temático. Uma vez que aí, quase de imediato, surge o horizonte necessário do gesto, ou melhor, de uma ação comprometida com atenção à chegada do "outro", o hóspede, que se dirige a alguém, o hospedeiro, na demanda de um acolhimento. Disso resulta, portanto, o circuito de uma situação não tão simples e confortável, posto que a vinda de alguém sempre provoque alguma alteração na cena habitual do lugar que o recepciona.

A encenação fílmica em Dogville exibe em sua narrativa o desdobramento de um drama, graças ao qual é possível reconhecer certos aspectos que estão vivamente presentes nos acontecimentos mais corriqueiros do nosso mundo empírico, dito real. O que já nos leva a considerar que estamos tratando aqui de algo que poderá estar tangivelmente muito próximo a qualquer um de nós. Sendo assim, passemos ao lócus da ação no drama da hospitalidade encenada pela obra supracitada.

\section{LóCUS DA AÇÃO NO DRAMA DA HOSPITALIDADE}

Em que pese o fato da narrativa cinematográfica estar patentemente alçada ao plano da "mostração" - na medida em que o suporte icônico da imagem aí seja capital -, no percurso das nossas considerações, iremos direcionar a atenção aos aspectos da estrutura narrativo-diegética, sobretudo dando relevo aos elementos da enunciação narrativa do filme ${ }^{3}$. Ademais, na medida do possível consideraremos os elementos imaginários da composição figural do âmbito cenográfico e seus respectivos signos.

2 Ao tratar da subjetividade em termos de uma "metafísica da alteridade", Lévinas ressalta "Elle est attention à la parole ou accueil du visage, hospitalité et non pas thématisation" (Cf. LÉVINAS, Emmanuel. Totalité et infini: essai sur l'extériorité. 12. ed. Paris: MauryImprimeur, 2009, p. 334).

3 A propósito da enunciação no campo do cinema, segundo Jacque Aumont e Michel Marie: "A enunciação é o que permite a um filme, a partir das potencialidades inerentes ao cinema, ganhar corpo e manifestar-se. [...] As teorias da enunciação permitiram levar em consideração a maneira pela qual o texto fílmico se desenha, se enraíza e se volta sobre si mesmo. A noção serve para salientar três momentos na produção do texto fílmico: o momento de sua constituição, o de sua destinação e seu caráter auto-referencial" (AUMONT, Jacques; MARIE, Michel. Dicionário teórico e crítico de cinema. Trad. Eloisa Araújo Ribeiro. Campinas: Papirus, 2003, p. 99).

178 Número temático: literatura e cinema. A Cor das Letras - UEFS, n. 11, 2010 
Porém, por se tratar de uma leitura psicanalítica da história contada pelo filme, abordaremos os signos imaginários com o intuito de articulá-los ao campo simbólico da linguagem discursiva, para identificar certos aspectos significantes na estrutura da trama que dá estofo ao drama representado pelas personagens. Isso significa nos referirmos à cena no drama como um lugar mais topológico que topográfico, considerando que o tópos ou lócus da ação no drama da hospitalidade se dá propriamente no tecido da linguagem discursiva.

Desse modo, perspectivamos a imagem em sua condição de suporte destinada ao cumprimento de sua função simbólica significante, razão pela qual se encadeia no engajamento imagético narrativo que compõe uma dada história. A partir desse horizonte é, com efeito, que reconhecemos o alcance da função significante da imagem, contextualizada por meio de um discurso que a sustenta segundo uma articulação que, inelutavelmente, põe em jogo o suposto sentido de alguma intenção, a partir de um ponto de vista que se salienta pela voz do narrador ${ }^{4}$.

Patentemente se verifica que, em Dogville, a narratividade constituise como traço basilar na estrutura da obra. A voz do narrador onisciente mantém-se como princípio organizador na condução e exposição das transformações relativas à sequência dos eventos que vão sendo contados e mostrados ao longo do filme.

A configuração da narrativa é composta por nove capítulos, um epílogo e um prólogo; este funcionando ao modo de uma moldura à história que virá em seguida.

Saliente-se que o prólogo tem a função de apontar algumas coordenadas da situação, além de despertar expectativas e, de algum modo, já

4 Cf. a palestra proferida por Lacan quando falou "Do símbolo e sua função religiosa", onde enuncia: "Trata-se de uma espécie de falha, percebida em algum lugar, entre a 'natureza' e o que se chama educadamente de 'cultura'. Aí é onde se dá a introdução da Lei, a lei tão mineral - da fala. Resta uma grande questão, a do equívoco em torno da imagem. Nossas tendências analógicas, nossos arquétipos, tudo o que nos dá a sensação de que o símbolo é uma coisa que já está aí e que nos chama, uma espécie de pré-formação na natureza de não sei que ordem, que se exalça pouco a pouco, tudo isso tem algo de confusional. Permitimo-nos interpretar tudo no mesmo plano. Claro, o mundo da imagem existe, mas só nos interessa por sua utilização simbólica, na medida em que é tomado no universo do símbolo e ali cumpre uma função" (LACAN, Jacques. O mito individual do neurótico, ou, A poesia e verdade na neurose. Trad. Cláudia Berliner. Rev. técnica Ram Mandil. Rio de Janeiro: Jorge Zahar Ed., 2008. Campo freudiano do Brasil, p. 66-67).

Cláudio Cledson Novaes, Fernanda Aguiar C. Martins, Roberto H. Seidel (Org.) 
oferecer certas pistas acerca do que irá se desenrolar na narrativa ${ }^{5}$, de sorte que, apresentando a cidade e seus habitantes, o prólogo do narrador em Dogville esboça o contexto no qual se dará a encenação, definindo assim os termos e as circunstâncias que balizarão as ações das personagens e seus efeitos de sentido na composição do drama.

É de se imaginar que, logo de início, possa chamar à atenção do expectador a própria economia da disposição espacial com que a "cidade" é mostrada. Ao modo de uma escrita cartográfica, cada ambiente, cada referência de território encontra-se indicialmente traçada sobre o chão ao longo de um vão. Residências sem paredes, pouquíssimos objetos compondo e ressaltando uma atmosfera tipicamente teatral, donde se avulta a importância conferida ao trabalho de atuação dos atores. E desta economia material dos objetos em cena é que emerge a relevância do papel do som, cujos efeitos simulam o abrir e fechar das portas, além da iluminação que se desloca metonimicamente, em geral pontuando seu foco sobre a cena protagonizada a cada momento. No final de cada capítulo, a luz se apaga completamente, restando, então, a tela negra sobre a qual se exibe um novo letreiro escrito em branco com a indicação do capítulo e o respectivo título seguinte, que dá condução à orientação da narrativa. São estes artifícios minimalistas na configuração estética desse filme que, provavelmente, reforçam no expectador, durante a fruição estética, o pacto do "como se" que dá selo e sustentação ao princípio da verossimilhança tão caro à consolidação da realidade mimética que caracteriza o universo ficcional.

É, por conseguinte, nesse jogo de tensões que já se reconhece desde o nível mais aparente da composição cenográfica e áudio-visual, a própria organização do espaço inscrevendo-se como elemento narrativo, e pelos quais se entrevê a estrutura irônica inerente à poiesis dessa obra. Vale notar ainda que a lógica desse mecanismo se faz notório ao modo de uma "Ironia Observável"” que suscita um jogo de tensões imaginárias, quiçá

5 Cf. REIS, Carlos; LOPES, Ana Cristina M. Dicionário de narratologia. Coimbra: Almedina, 1987, p. 335-336.

6 Remeto o leitor ao texto de Muecke no qual este autor delineia e analisa amiudemente o histórico conceito de ironia desde a sua aurora em Platão e Aristóteles aos empregos mais recentes. Quanto à Ironia Observável, diz o autor: "Mais próxima de dramática ou teatral do que a Ironia Instrumental é a Ironia Observável. Ironias de Evento, por exemplo, que atuam no tempo, têm uma estrutura dramática clara, o caso típico que envolve a vítima com certos medos, esperanças ou expectativas que, agindo com base neles, toma medidas para evitar um mal previsto ou tirar proveito de um bem previsto; mas suas ações servem apenas para enredá-la numa cadeia casual que leva inevitavelmente à sua 
querendo demonstrar com esse artifício quando o máximo de visibilidade aparentemente objetiva vem ao encontro da mais flagrante e óbvia cegueira, incrustada nos preconceitos que emparedam a percepção comum das pessoas. Eis a mostração de um curioso paradoxo que se exibe sob a forma de uma transparência obscurecedora, operando ironicamente na estrutura dessa situação dramática, de sorte que os efeitos dessa estrutura irônica provocam no expectador o ensejo de se pensar algo querendo se revelar para além da sintaxe imaginária desses elementos aparentes do filme, de modo a se suspeitar da possibilidade da abertura de outro campo semântico a respeito da mensagem contextual referente ao tal lugar, o qual daí em diante se oferece a título de uma alegoria metafórica que, por sua vez, poderá nos remeter a tantos outros lugares.

$\mathrm{Na}$ abertura do filme, o traçado indicial da cidade é visto de cima, numa tomada superior, enquanto a voz do narrador anuncia: "Esta é a triste história da cidade chamada Dogville". A referência contextual deste lugar é exibida sob a imagem de um expresso abandono. As pontuações do narrador situam este vilarejo no fim absoluto de uma estrada, ao lado de uma velha mina abandonada, além do aspecto miserável da maioria das casas, que surgem tal como ele refere: "mais pareciam barracos".

Dogville põe em cena a questão da hospitalidade dando-se entre a vida habitual desta cidadela e uma fugitiva que aí chega, demandando abrigo para se proteger de supostos perseguidores. Grace, o seu nome. Recepcionada por Thomas Edison Jr., o Tom, que por sua vez a apresenta aos outros moradores propondo acolhê-la, posto que, no seu entender, havia entre os cidadãos o problema de não lidar com a "aceitação". Grace é aceita, então, por duas semanas a título de um teste. Enquanto isso se propõe a ajudar a cada um dos moradores, como uma forma de pagamento pelo fato de ter sido "aceita", empenhando-se em realizar tarefas nos afazeres habituais do cotidiano. Todavia, por ser tida como uma fugitiva dos gângsteres, isso já se traduz como motivo o suficiente para deixá-la moralmente endividada com os moradores, apreensivos pelo risco de acolhê-la, acobertando-a nessa condição clandestina. Essa situação vai até que, como informa o narrador no título do capítulo $\mathrm{VI}$, chega o dia "Quando Dogville mostra os dentes". Doravante, o que se assiste é ao que antes parecia hospitalidade se

ruína. Esta descrição abstrata da Ironia de Eventos também serviria para o esqueleto do enredo de uma tragédia, como As Bacantes, King Lear ou The Revenger's Tragedy" (MUECKE, D. C. Ironia e o irônico. Trad. Geraldo Gerson de Souza. Rev. Vera Lúcia Beluzzo Bolognani e Valéria Cristina Martins. São Paulo: Perspectiva, 1995, p. 90-91). 
transformar numa prisão. Grace se torna refém da cidade, passando a ser explorada por todos, dos mais velhos às crianças, inclusive sexualmente abusada pelos homens, cujas visitas, nas palavras do narrador: "Não eram bem um ato sexual. Elas eram uma vergonha, assim como quando um caipira usa uma vaca. Nada, além disso". A essa altura, Tom assiste a tudo impotente, até que tenta engendrar mais um plano para que Grace consiga fugir e se livrar das sevícias sofridas ali. Contudo, este plano também fracassa e ela permanecerá, a partir de então, com uma coleira acorrentada ao pescoço, a qual se prende a uma pesada roda de ferro que, caso queira se movimentar, terá que ser arrastada sobre o chão. Tom, "especialista em assuntos morais", propõe mais um plano que consiste em fazer com que, diante de uma reunião, Grace fale tudo o que pensa a respeito dos moradores de Dogville. Os habitantes diante do desmascaramento não suportam mais a convivência com Grace e finalmente Tom, já se sentindo responsável por todo o mal-estar na vida da cidade, resolve, enfim, ligar para o gângster para delatar a existência da tal fugitiva naquela comunidade. Com a chegada dos gângsteres - e talvez o ápice da revelação na estrutura irônica dessa trama narrativa - , eis que o chefe dos gângsteres é o pai de Grace. Esta tinha se afastado dele, após uma discussão familiar entre pai e filha, por não querer ser como ele. No último diálogo entre pai e filha, e já sabendo ele dos "problemas" enfrentados e sofridos pela filha com aquela comunidade, ele pede para que ela volte com ele e estende a ela todo o seu poder no sentido de decidir sobre o destino de Dogville. Após alguma hesitação, Grace, enfim, sanciona sua sentença, afirmando: "O mundo ficará melhor sem essa cidade".

Pensar a hospitalidade enquanto drama $^{7}$ significa advertir quanto às dificuldades inexoráveis que se instalam e emergem entre os sujeitos aí envolvidos. É mesmo no delicado circuito que enlaça o "eu" e o "outro", que se abre o campo donde costumam surgir todos os problemas concernentes às necessárias negociações para que haja, enfim, possibilidade de coabitação e convivialidade.

Por sua vez, o drama em psicanálise é, ao mesmo tempo, como observa Lacan, "o drama da psicanálise", posto que a condição, para que um

7 Da etimologia grega, a acepção do vocábulo "Drama", surge originariamente referindo-se ao sentido da ação. Embora seja válido empregar esse termo no campo ficcional poéticoliterário, "essencial e historicamente, a palavra 'drama' vincula-se ao teatro, isto é, à arte da representação" (Cf. MOISÉS, Massaud. Dicionário de termos literários. 7. ed. São Paulo: Cultrix, 1995, p. 161-163).

182 Número temático: literatura e cinema. A Cor das Letras - UEFS, n. 11, 2010 
ato venha a ser significante, é que ele precisará ser devidamente simbolizado através da fala. Daí, ele enunciar:

Todo homem moderno tem o coração atormentado por esse problema: "No começo, era o verbo", mas, assim mesmo, "No começo, era a ação"! Entre ambos, seu coração balança. Ele realmente não precisa se atormentar tanto, pelo motivo de que a ação humana por excelência é precisamente a fala ${ }^{8}$.

E, um pouco mais adiante, observa ainda Lacan:

Ora, o drama da psicanálise é ser uma ação humana tão fundadora, tão integrada à própria ação da fala que ela comporta uma responsabilidade suprema, total, quase intolerável para aqueles que são seu suporte ${ }^{9}$.

Quer dizer, todo o drama da psicanálise remete ao sujeito falante que, na condição de suporte da "ação da fala", se vê no desafio de se reconhecer e, por conseguinte, responder àquilo que advém inconscientemente por meio dos seus ditos, que o relançam na dimensão de "responsabilidade, total, quase intolerável". É, pois, precisamente aí onde situamos em termos psicanalíticos o tópos desse lugar como lócus da ação no drama da hospitalidade - quer dizer, é na relação do sujeito com a linguagem onde se delineia o território pelo qual se dramatiza a ação da linguagem por via de um discurso, cujos efeitos são suportados por um sujeito.

Convém lembrar, com Derrida, que é no risco de se dizer "boas vindas", onde repousa a suposição de quem se insinua saber estar na própria casa. Donde talvez caiba enunciar a seguinte questão: mas, de qual casa, qual morada, de qual lugar, de qual habitação, em suma, adviria tal convite? Ora, não seria mediante uma saudação assim que se vislumbraria a abertura de uma porta, cuja promessa indicaria acesso a um circuito pulsional de hospitalidade?

8 LACAN, Jacques. O mito individual do neurótico, ou, A poesia e verdade na neurose. Trad. Cláudia Berliner. Rev. técnica Ram Mandil. Rio de Janeiro: Jorge Zahar Ed., 2008. Campo freudiano do Brasil, p. 53.

9 Idem, p. 54 - grifo meu.

Cláudio Cledson Novaes, Fernanda Aguiar C. Martins, Roberto H. Seidel (Org.) 


\section{O CIRCUITO PULSIONAL DA HOSPITALIDADE}

O terceiro não espera, sua eleidade conclama desde a epifania do rosto no face-a-face (Jacques Derrida).

Na ocasião do circuito instaurado pela hospitalidade, se faz indefectível, no meu entender, a ideia do movimento implicando a conotação da passagem numa espécie do parto em função de uma travessia. Por isso, evoco a noção da pulsão para figurar o sentido desse movimento relacional entre o "eu" e o "outro".

Aliás, será oportuno mencionar o curioso paradoxo que Derrida detecta a título da "metafísica da alteridade" no pensamento de Lévinas:

A hospitalidade supõe a "separação radical" como experiência da alteridade do outro, como relação ao outro, no sentido que Lévinas sublinha e trabalha na palavra "relação", no seu alcance ferencial, referencial, ou antes, como ele assinala por vezes, deferencial. A relação ao outro é deferência. Tal separação significa aquilo justamente que Lévinas renomeia a "metafísica": ética ou filosofia primeira por oposição à ontologia. Porque ela se abre, para acoIhê-la, à irrupção da idéia do infinito no finito, esta metafísica é uma experiência da hospitalidade ${ }^{10}$.

Admitir a priori uma "separação radical" na "relação ao outro" assinala, portanto, desde o seu nascedouro um campo de experiência pautado pelo desafio, que ademais justifica a possibilidade do drama que já se funda na arkhé originária dessa relação. Isto pelo fato da recepção marcar-se pela "deferência" diante da necessária acepção da "alteridade do outro", de modo que, no ato do acolhimento, da recepção, é que surge o paradoxo que se inscreve na condição de reconhecer, desde já, a "separação radical", hospedando aí, no interior mesmo mais íntimo deste acolhimento, o reconhecimento ético da alteridade do inelutavelmente outro, inacessível e inapreensível a qualquer pretensão colonizadora e domesticante.

Freud, todavia, já abrira o caminho, apontando no interior do próprio "eu" a emergência desta experiência, sinalizando-a quiçá como traço fundamental da subjetividade humana, tendo a denominado por unheimlich, quer dizer: a sensação de se estar sem-lar, um "eu sem-lar", de repente acometido por algo que se diz "estranhamente familiar".

10 DERRIDA, Jacques. Adeus a Emmanuel Lévinas. Trad. Fábio Landa com a colaboração de Eva Landa. São Paulo: Perspectiva, 2008, p. 64 - grifos meus.

184 Número temático: literatura e cinema. A Cor das Letras - UEFS, n. 11, 2010 
Daí a entranhada ligação dessa situação com a figura da ironia, visto que a perturbação causada pela chegada do outro sinaliza, no mínimo, a derrisória subversão que desbanca a ilusão pretendida do sentido unívoco pautado na verdade única, quer seja dentro ou fora do sujeito. Talvez, por isso, o traço irônico na voz do narrador que, ao sustentar-se por essa posição enunciativa, exerce assim papel capital à dimensão semântica e significante na trama representada pelo drama da hospitalidade canibal em Dogville.

As pontuações sutis da enunciação narrativa vão se inscrevendo numa relação de agudo questionamento aos elementos referencias desse contexto situacional, cujo alvo coloca a ironia em ação atingindo a moralidade de uma América profundamente provinciana, moralista e conservadora. Quem sabe, uma espécie de crueldade irônica que advém da parte do narrador, apontando a miséria de uma suposta civilização que, aliás, se reflete real, simbólica e imaginariamente em outras áreas do mundo e da cultura ocidental? Isto se comprova, inclusive, ao final do filme, quando se assiste a exibição de uma sessão de fotos em preto e branco, com pessoas em ambientes situados no contexto real dos trabalhadores das minas, no interior dos Estados Unidos, cuja paisagem humana é de franca decadência e desolação.

É possível que uma das funções dessa estratégia enunciativa tenha por objetivo promover no interlocutor, leitor ou expectador a percepção de uma ideia contrária, insinuando-se sob a "boa" imagem produzida e consumida usual e normalmente nas montagens ideológicas que conformam a instauração do bom-senso e do senso-comum. Por essa razão, é mesmo pelos meandros da ironia na voz do narrador que supomos situar a questão do drama trágico da hospitalidade canibal em Dogville, na medida em que os destinos deste lugar e de toda a comunidade terminam ficando à mercê da decisão caprichosa da sua "hóspede-refém", Grace.

A história do filme pôs a questão da hospitalidade acontecendo a título de uma provação, pela qual o drama vivenciado por Grace se confunde com o da própria cidade que estaria passando também pelo teste arquitetado por Tom, cujo intuito, segundo o narrador, seria "Provar que cidadão algum lidava bem com a aceitação". Todavia, nesse jogo que envolve um trabalho de aprendizagem mútua, gera-se o risco de, na travessia do circuito da hospitalidade, ao se conhecer o "outro", não se suportar o processamento da verdade nas revelações e desmascaramentos daí decorrentes. É neste sentido que Derrida afirma que: 
Movemo-nos nos meandros obscuros de uma familiaridade semântica, senão etimológica, entre hóspede e refém, entre o sujeito como hóspede e o sujeito (ou a ipseidade) como refém. Que se subentenda na palavra "refém" (ostage) um hóspede dado ou recebido em penhor substitutivo nos lugares do poder e à disposição do soberano, ou que se subentenda o obsidium ou obsidatus (condição de refém ou de cativo) a partir de uma situação obsidional, permanece possível, segundo as duas vertentes, de reencontrar o penhor da substituição ("acusação de todos", "a responsabilidade por todos"), a saber, a passagem que abre Lévinas entre estas duas figuras da mesma ética: a hospitalidade sem propriedade e a "obsessão persecutória" do refém. Como já pudemos lembrar, fica atestada a genealogia que liga o termo de ipseidade (desde sempre no centro do discurso de Lévinas) à semântica da hospitalidade, do hospes como hosti-pet-s, isto é, o mestre do hóspede, onde as significações do si-mesmo, do controle, da posse, do poder se emaranham numa rede cerrada, vizinha da hospitalidade do hostis ${ }^{11}$.

A longa citação acima comporta o valor de precisamente apontar à delicadeza do paradoxo que conjuga a encruzilhada por onde "se emaranham numa rede cerrada" o risco de se cair no que Lacan chamaria de a sedução do estado confusional do eu com o outro. Cair no estado confusional significa tornar-se refém, paralisado na identificação com o Outro imaginário. Disso resulta exatamente a imagem do fracasso da hospitalidade, quando esta resvala, não em se cumprir ao modo de um lugar de passagem, mas refletindo apenas o impasse traduzido por "uma situação obsidional". É que a ética da hospitalidade se avulta na legitimação do que se inscreve precedendo a própria lei da propriedade, da posse e da retenção que, inclusive, desemboca na "obsessão persecutória do refém".

Todavia, a saída de tal "situação obsidional" de modo a fazer valer o direito de ir-e-vir requer a chegada de algo que ultrapasse as obstruções do imaginário, algo que efetivamente vá para além das tentações paranóicas da ilusão de controle sobre o outro. É, pois, nesta encruzilhada que Lacan salienta a ação da linguagem na sua função de reconhecimento na relação com o semelhante, chegando a citar o exemplo da questão da senha como um dos modos mais rudimentares de se lançar mão do código da linguagem para efetuar uma passagem. E Derrida, por sua vez, relembra as últimas palavras de Lévinas, em Totalidade e infinito, onde se lê que "[...] a essência da linguagem é bondade, ou ainda [...] a essência da linguagem é amizade e hospitalidade"12.

\footnotetext{
11 DERRIDA, Jacques. Adeus a Emmanuel Lévinas. Op. cit., p. 74-75.

12 Idem, p. 68.
}

186 Número temático: literatura e cinema. A Cor das Letras - UEFS, n. 11, 2010 
A transitividade não-violenta desse momento, portanto, só se efetuará, enfim, com a convocação dessa terceira instância que atende pelo nome de Linguagem, o Outro inscrito e legitimado pelo registro do Simbólico. Eis, pois, o mediador que, nas palavras de Derrida,

Este sobrevém sem esperar. Sem esperar, ele vem afetar a experiência do rosto no face-a-face. Esta interposição do terceiro, esta "terceiridade", se ela não se interrompe, seguramente, o próprio acolhimento, ela envia ou desvia para si o duelo do face-a-face, o acolhimento singular da unicidade do outro como testemunha (terstis) para dela testemunhar ${ }^{13}$.

Por essa via de "interposição do terceiro" é que nos reencontramos com o que citei anteriormente, como sendo o próprio drama da psicanálise no que tange a sustentar a função do sujeito na estrutura do significante articulada às leis da linguagem.

Por minha hipótese de leitura, sinalizo que o que se assiste na representação fílmica do drama entre Grace e os habitantes de Dogville, é a encenação da face canina de uma hospitalidade que desemboca em um trágico fracasso de ambas as partes. Não obstante as discordâncias e aposições que ela desfere contra o pai, por este ter se transformado num gângster, o fato é que em sua sentença termina identificando-se com a lei perversa deste, cujo princípio se norteia pelo primado da vingança - uma justiça que se mede calcando-se pela lei do Talião. Eis a face imaginária da lei que não legaliza, por só se efetuar mediante os caprichos da parcialidade, não havendo lugar para a chegada da instância que se interpõe entre a dualidade em função de uma terceiridade no Outro simbólico conferido pela linguagem.

Essa lei inscrita e legitimada imaginariamente só se cumpre a título de fetiche, máscara e arremedo do grande Outro, porque encarnada na pseudo-alteridade do pequeno "outro" que, passando ao ato da encarnação crua do real, mostra em carne e osso a face canina de uma lei que desemboca fatalmente na consumação trágica da violência; violação que antes consiste em violar a lei da linguagem simbólica, estofo comum das possíveis negociações dos direitos entre os sujeitos. Eis a morada transitória do homem, segundo Lacan:

"O homem habita a linguagem"; mesmo extraído do texto de Heidegger, isso fala por si só. Isso quer dizer que a linguagem está aí antes do homem, o que

13 Idem, p. 46.

Cláudio Cledson Novaes, Fernanda Aguiar C. Martins, Roberto H. Seidel (Org.) 
é evidente. Não apenas o homem nasce na linguagem exatamente como nasce no mundo, como nasce pela linguagem ${ }^{14}$.

Pro outro lado, Tom que, segundo a apresentação irônica do narrador de Dogville, "era um escritor. Pelo menos, a seu próprio ver. Toda a sua obra até então se resumia às palavras 'grande' e 'pequeno' seguidas de ponto de interrogação... mas meticulosamente arquivada em uma de suas gavetas", protagoniza o papel de porta-voz e agenciador do processo de enunciação coletiva por via das reuniões que organizava em prol do "rearmamento moral" para beneficiar a cidade; sendo neste caso, a própria representação do fracasso da função simbólica da linguagem. Ele personifica a face decadente do discurso metafísico que predominou na estrutura enunciativa dos discursos no mundo ocidental. A face da razão aporética, negativa e não propositiva do Outro, cujos impedimentos inviabilizam qualquer iniciativa de emancipação no sentido de favorecer a emergência e o desenvolvimento do sujeito humano, que fica assim refém do impasse que o retém numa posição narcisicamente inconsistente, desarticulada e infantil, espécie de enfans perante a linguagem.

Desse modo, no final, numa das últimas cenas do filme resta o Cão Moisés - alusão, quem sabe, à Lei inflexível do Antigo Testamento? -, único sobrevivente da chacina promovida pela sanção de Grace. O cão Moisés sai da sua condição de mero esboço desenhado sobre o chão, se apresentando em sua face vivamente encarnada, o cão em si: a metáfora encarnada da cidade, tal como sugerira o narrador, no capítulo 6, cujo título é: "Quando Dogville mostra os dentes".

\section{CONSIDERAÇÕES FINAIS: SINTOMA DE UM “INCONSCIENTE NO COLETIVO" OU “O FUNDO SEM FACE QUE FALA ROSNANDO"}

Tornou-se bastante usual se afirmar que é próprio à arte desrecalcar certas verdades normalmente não admitidas. Entretanto, e como já se sugere a semântica da palavra "arte", convém reconhecer que o que resulta enquanto obra não se dá senão mediante um trabalho, cujo fazer (poiesis) se engendra com a condição de se observar certos artifícios que lhe são intrínsecos ao seu funcionamento. É que, por se expressar como uma forma

14 LACAN, Jacques. Meu ensino. Trad. André Telles. Rio de Janeiro: Jorge Zahar Ed., 2006, p. 36.

188 Número temático: literatura e cinema. A Cor das Letras - UEFS, n. 11, 2010 
de linguagem, a arte só se constitui articulando-se consoante a atenção de suas próprias regras.

Não será difícil admitir que, a exemplo da representação fílmica, mais que tema - ou mero evento banal que se dá usualmente em sua face mais empírica e objetiva, isto é, no plano fenomênico mesmo da aparência dos acontecimentos - a hospitalidade se anuncia como o próprio estofo do qual parte, como diria Derrida, o "nascimento da questão", uma questão que consigo convoca a indefectível participação de outros vetores que a ela são indissociáveis, como a ética, a política e o direito.

Eleger uma obra ficcional para tratar da questão da hospitalidade, no meu entender, reveste-se de pertinência, tendo em vista as dificuldades e os conflitos que se multiplicam em profusão na face do mundo contemporâneo, nos mais variados planos da convivialidade entre os seres humanos. Isso implica em reconhecer no cinema um meio por onde a linguagem estética, além de entreter, empenha-se com atenção a certos problemas que envolvem o devir e o porvir da condição humana.

Com efeito, quem sabe seja mesmo o caso de se considerar o funcionamento da imagem artística como constituinte de um sintoma ${ }^{15}$. Sintoma, não de um "inconsciente coletivo", porém, sintoma de um inconsciente "no" coletivo ${ }^{16}$, o que é coisa bem distinta, dado o alcance que comporta

15 Cf. a esse respeito as observações de Jacques Aumont, quando este trata das relações entre a imagem e a psicanálise, em "O espectador como sujeito desejante" (AUMONT, Jacques. A imagem. Trad. Estela dos Santos Abreu e Cláudio C. Santoro. Campinas: Papirus, 1993. Coleção Ofício de Arte e Forma, p. 115).

16

Cabe lembrar o que Lacan enuncia ao se reportar a esse tema, proferindo em palestra e tentando elucidar a respeito do "Símbolo e sua função religiosa" que "O mesmo se aplica ao uso da noção de inconsciente como coletivo. Proclamo-o diante do público que me ouve, desafio alguém a me dizer o que quer dizer inconsciente coletivo. Quanto a mim, não sei absolutamente nada sobre isso, a não ser defini-lo como o discurso sem significação, o flatus vocis, o som e a fúria das palavras humanas, o discurso insensato na medida em que une, em sua vibração geral, aqueles que são seu suporte. No conjunto, a coletividade não sabe o que diz e, na verdade, passamos muito bem sem isso. 0 discurso conserva um valor, independentemente de qualquer sentido assumido. Como disse em algum lugar Mallarmé, 'o discurso humano é algo parecido com aquela moeda com a imagem apagada que passamos de mão em mão'. E isso serve para algo. Serve para a gente não se agarrar pelos cabelos, não se cortar o pescoço todas as vezes! Jogamos conversa fora e, graças a isso, Deus do céu, a gente parece se entender, o que já é suficiente. O inconsciente coletivo, digamos assim, é isso, é o que todo mundo conta, histórias de visconde, não é mesmo?" (LACAN, Jacques. O mito individual do neurótico, ou, A poesia e verdade na neurose. Trad. Cláudia Berliner. Rev. técnica Ram Mandil. Rio de Janeiro: Jorge Zahar Ed., 2008. Campo freudiano do Brasil, p. 51-52).

Cláudio Cledson Novaes, Fernanda Aguiar C. Martins, Roberto H. Seidel (Org.) 
essa questão nos termos em que está sendo encarada aqui. Tal sintoma sinaliza ao modo de um apelo quanto aos riscos envolvidos em certas situações, isto, na medida em que conseguimos assinalar a partir dessa representação imaginária o tópos de uma via dramaticamente trágica figurada pela metáfora de uma cidadela canina, cuja população parece viver tranquilamente, na comodidade da própria cegueira. Significa apontar aí a configuração de um liame pelo qual se conjugam um ethos e um pathos, que, por sua vez, selam a determinação de um pacto, cuja sustentação se dá graças à negação perversa dos desmentidos, haja vista os mecanismos de alienação trans-subjetivos que daí decorrem em função da presença dos mecanismos operadores do inconsciente "no" coletivo. Talvez, a metáfora paradigmática da atuação desses mecanismos esteja figurada na personagem do cego Mc Kay. Ora, como não notar recair sobre esta personagem a própria condensação do pacto de cegueira com que se autentica na relação de tapeação com os demais habitantes que, como ele, finge negando a verdade da sua condição de cego? Seria por acaso exagero notar, no plano dessa relação de tapeação, um pacto que os mantêm ironicamente na condição de hóspedes da cegueira? Eis, pois, a função do inconsciente "no" coletivo operando no sentido de manter, tal como o cego Mc Kay, a negação desmentida de uma verdade, fingindo ter uma visão perfeita que, todavia, após ter sido desmascarado por Grace, dirige-Ihe em tom de apelo e, ao mesmo tempo, de comando: "Por favor, vá. E me deixe ser cego em paz". Da insuportabilidade da verdade ${ }^{17}$, resta apenas a decisão inóspita e hostil para com o outro, lançando mão da exclusão paranoica como único expediente para se manter na mesma posição, mesmo que isso lhe custe a ter o semelhante na conta de uma virtual ameaça.

Além do mais, cabe ainda mencionar um momento da encenação em que, no meu entender, se ilustra filmicamente a mostração do impasse numa realidade enguiçada, figurada na alegoria aporética da "roda que não roda", presa ao pescoço de Grace.

Apontar a suscetibilidade dos riscos e perigos a partir da ereção da imagem da hospitalidade canibal significa referir a tragicidade acarretada

17 A propósito da questão da "violência simbólica", remeto o leitor ao artigo de Roberto H. Seidel, no qual este autor tece valiosas reflexões sobre modalidades de violência institucional no âmbito da cultura contemporânea (SEIDEL, Roberto H. Violência simbólica. In: NOVAES, Claudio C.; SEIDEL, Roberto H.; SOUZA, Licia S. de. (Org.). Figuras da violência moderna: confluências Brasil/Canadá. Feira de Santana: NEC/UEFS Editora, 2010, p. 159176).

190 Número temático: literatura e cinema. A Cor das Letras - UEFS, n. 11, 2010 
pela modalidade de um drama, tal como diria o narrador ironicamente na frase que pusemos como epígrafe deste artigo: "Dogville pode ficar longe de tudo, mas é muito hospitaleira, é claro".

O triunfo da lógica da vingança se traduz na perspectiva psicanalítica como a face fracassada da Lei do Pai que resvala na lei do Talião que só se sustenta na inconsistência bruta de uma posição calcada na Cão-viç̧ão, como diria o trocadilho de Lacan em um dos seminários em que enuncia:

Recusei-me, a partir da idéia de que as pessoas que não querem nada comigo, eu, não procuro convencê-las. Não se deve cãovencer. O próprio da psicanálise é de não vencer, cão ou não ${ }^{18}$.

Decerto que, insistir por esse caminho, talvez só reste, como observou Deleuze a propósito da ironia, "o Fundo sem face que fala rosnando"19.

Todavia, algo subjaz ainda no cerne do drama trágico de uma hospitalidade canibal, e que preferirei deixar para o leitor em forma de citação para concluir este artigo, só para fazer soar como derradeira observação a própria palavra do narrador que finaliza o filme deixando no ar uma questão: "Quando Grace deixou Dogville, ou Dogville deixou Grace e o resto do mundo?"

18 LACAN, Jacques. O seminário: livro 20: mais, ainda. Texto estabelecido por Jacques-Alain Miller. Versão bras. M. D. Magno. 2. ed. Rio de Janeiro: Jorge Zahar Ed., 1985, p. 72 - grifo meu.

19 Cf. Em seu brilhante livro-ensaio de "romance lógico e psicanalítico", Lógica do sentido, na parte referente ao Humor quando, depois de discorrer sobre a aventura do humor no sábio estóico que, nos seus torneios de linguagem encontra os "puros acontecimentos" efetuando-se como objeto não apenas em termos de algo designado ou significado na linguagem platônico-idealista, mas objeto como expresso ou exprimível, Deleuze arremata enunciando que: "O que há de comum a todas as figuras da ironia é que elas encerram a singularidade dos limites do indivíduo ou da pessoa. Por esse motivo a ironia não é vagabunda senão na aparência. Mas, sobretudo, é porque todas estas figuras estão ameaçadas por um inimigo íntimo que as trabalha de dentro; o fundo indiferenciado, o semfundo de que falávamos precedentemente e que representa o pensamento trágico, o tom trágico com qual a ironia mantém as mais ambivalentes relações. É Dionísio sob Sócrates, mas é também o demônio que estende a Deus assim como as suas criaturas o espelho em que dissolve a universal individualidade e ainda o caos que desfaz a pessoa. $O$ indivíduo pronunciava o discurso clássico, a pessoa, o discurso romântico. Mas, sob estes dois discursos e invertendo-os de maneiras diversas, é agora o Fundo sem face que fala rosnando" (DELEUZE, Gilles. Lógica do sentido. Trad. Luiz Roberto Salinas Fortes. São Paulo: Perspectiva, 1974, p. 142 - grifo meu). 


\section{REFERÊNCIAS}

AUMONT, Jacques. A imagem. Trad. Estela dos Santos Abreu e Cláudio C. Santoro. Campinas: Papirus, 1993. Coleção Ofício de Arte e Forma.

AUMONT, Jacques; MARIE, Michel. Dicionário teórico e crítico de cinema. Trad. Eloisa Araújo Ribeiro. Campinas: Papirus, 2003.

DELEUZE, Gilles. Lógica do sentido. Trad. Luiz Roberto Salinas Fortes. São Paulo: Perspectiva, 1974.

DERRIDA, Jacques. Adeus a Emmanuel Lévinas. Trad. Fábio Landa com a colaboração de Eva Landa. São Paulo: Perspectiva, 2008.

DOGVILLE. França em co-produção com Dinamarca, Suécia, Noruega, Finlândia, Reino Unido e Países Baixos. Direção: Lars Von Trier. Elenco: Nicole Kidman, Harriet Anderson, Lauren Bacall, Jean-Mare Barr, Paul Bettany, Blair Brown e James Caan. Produtora: Zentropa Enterteinment, 2003. 1 DVD vídeo. $171 \mathrm{~min}$.

LACAN, Jacques. Meu ensino. Trad. André Telles. Rio de Janeiro: Jorge Zahar Ed., 2006.

LACAN, Jacques. O mito individual do neurótico, ou, A poesia e verdade na neurose. Trad. Cláudia Berliner. Rev. técnica Ram Mandil. Rio de Janeiro: Jorge Zahar Ed., 2008. Campo freudiano do Brasil.

LACAN, Jacques. O seminário: livro 20: mais, ainda. Texto estabelecido por Jacques-Alain Miller. Versão bras. M. D. Magno. 2. ed. Rio de Janeiro: Jorge Zahar Ed., 1985.

LÉVINAS, Emmanuel. Totalité et infini: essai sur l'extériorité. 12. ed. Paris: Maury-Imprimeur, 2009.

MOISÉS, Massaud. Dicionário de termos literários. 7. ed. São Paulo: Cultrix, 1995.

MUECKE, D. C. Ironia e o irônico. Trad. Geraldo Gerson de Souza. Rev. Vera Lúcia Beluzzo Bolognani e Valéria Cristina Martins. São Paulo: Perspectiva, 1995.

REIS, Carlos; LOPES, Ana Cristina M. Dicionário de narratologia. Coimbra: Almedina, 1987.

SEIDEL, Roberto H. Violência simbólica. In: NOVAES, Claudio C.; SEIDEL, Roberto H.; SOUZA, Licia S. de. (Org.). Figuras da violência moderna: confluências Brasil/Canadá. Feira de Santana: NEC/UEFS Editora, 2010, p. 159-176. 